\title{
Fatty Acids Profile of Coffea arabica L. Resistant to Leaf Rust Grown in Two Environments of Minas Gerais, Brazil
}

\author{
L. O. Fassio ${ }^{1}$, M. R. Malta ${ }^{1}$, G. R. Carvalho ${ }^{1}$, G. R. Liska ${ }^{2}$, P. M. Lima ${ }^{3}$, D. H. S. Nadaleti ${ }^{4}$, \\ A. J. Fonseca ${ }^{1} \&$ C. J. Pimenta ${ }^{4}$ \\ ${ }^{1}$ Empresa de Pesquisa Agropecuária de Minas Gerais, Lavras, Brazil \\ ${ }^{2}$ Universidade Federal do Pampa, Itaqui, Brazil \\ ${ }^{3}$ Universidade de São Paulo, Pirassununga, Brazil \\ ${ }^{4}$ Universidade Federal de Lavras, Lavras, Brazil \\ Correspondence: L. O. Fassio, FAPEMIG, Empresa de Pesquisa Agropecuária de Minas Gerais, Lavras, Brazil. \\ Tel: 55-35-99845-8303. E-mail: larissafassio@yahoo.com.br
}

\author{
Received: August 9, $2017 \quad$ Accepted: October 17, $2017 \quad$ Online Published: November 15, 2017 \\ doi:10.5539/jas.v9n12p88 URL: https://doi.org/10.5539/jas.v9n12p88
}

The research is financed by Consórcio Pesquisa Café, FAPEMIG, CNPq, CAPES.

\begin{abstract}
The quality of the coffee drink is defined by its sensorial attributes which are developed through the chemical predecessors found on raw grains. Due to this relation, this present work had a goal evaluating the sensorial characteristics of resistant coffee cultivars to leaf rust for the production of specialty coffee and correlate them with the profile of fatty acids present on raw grains, enabling the distinction of cultivars in two environments of Minas Gerais. For this purpose, seven cultivars of Coffea arabica resistance to leaf rust were evaluated and two susceptible cultivars, in two growing environments: Lavras, in the South of Minas Gerais and Patrocínio, in the Cerrado of Minas Gerais. The C16:0, C16:1, C18:0, C18:1, C18:2 $\omega-6$, C18:3 $\omega-3$ fatty acids common in coffee grains, were identified in the cultivars. The presence of an acid uncommon in coffee grains, the gamma linolenic acid (C18:3 $\omega-6$, GLA) was also detected. The palmitic and alpha linolenic fatty acids presented correlation with the sensorial quality of the drink. The linoleic, palmitic, alpha linolenic and gamma linolenic fatty acids were capable to differentiate the Patrocinio and Lavras environments. The profile of the fatty acids permitted differentiate the leaf rust resistant cultivars, the environments as also the interaction between these two matters related to the sensorial quality.
\end{abstract}

Keywords: fatty acids, specialty coffee, gamma linolenic acid

\section{Introduction}

The coffee distinctive taste is due to the presence of levels of different volatile and no volatile chemical constituents, such as aldehydes, ketone acids, sugar, protein, amino acids, fatty acids and phenolic compounds (Vilas Boas et al., 2005). The coffee characteristics of flavor and aroma are result of a combination of thousands of chemical compounds produced through reactions that occur during the roast process, being the constituents of the green grains the predecessors of the final flavor of the coffee drink (Franca, Mendonça, \& Oliveira, 2005).

Many efforts have been made in the last recent years to find efficient methods to determine with accuracy the chemical composition of coffee grains from the two of the most important commercialized cultivars: Coffea arabica and Coffea canephora (Speer \& Kolling-Speer, 2006). The understanding of the chemical composition of the grains allows distinguish the species and validate the geographic region, in other words, determine terroirs coffee.

Coffee is rich in lipids, with variable levels to the cultivars Arabica and Robusta. The matter for arabica grains varies between 12 and 18\%, and for robusta grains between 9 and 14\%, and also play an important role in the sensorial quality of the drink (Clifford, 1985; Gutkoski \& El-Dash, 1999). Within the fatty acids found in the coffee seed, some recent researches have shown the influence of the palmitic, stearic, elaidic, oleic, linoleic, 
linolenic and arachidic acids in the quality of the coffee and also in the differentiation of environments (Bertrand et al., 2008; Figueiredo et al., 2015; Jham et al., 2008; Vilarreal et al., 2009).

According to Borém et al. (2013) the sensorial and chemical quality of the coffee grains are relevant elements to the production of specialty coffee. When the sensorial attributes and the chemical compounds of the coffee are studied, the possible differences found between them are basically related to the variety and species of coffee and to cropping environments.

Therefore, the objective of this work was determine if there is relation between the content of the fatty acids with the sensorial attributes found in the arabica coffee cultivars resistant to leaf rust. Just as well to verify if exist modifications in the chemical composition of the grains on this cultivars according to the weather conditions that enable the differentiation of the cultivars in different environments.

\section{Method}

\subsection{Experimental Conditions}

Were evaluated seven Coffea arabica L. cultivars resistant to rust, developed by the breeding program coordinated by Empresa de Pesquisa Agropecuária de Minas Gerais (EPAMIG) in partnership with the Universidade Federal de Viçosa (UFV) and Universidade Federal de Lavras (UFLA), and two rust-susceptible cultivars, which were used as control. The cultivars bourbon amarelo and topázio MG1190 were used as benchmarks for being cultivars traditionally grown in Minas Gerais. The studied cultivars have been established in the field in a randomized block design (RBD) with three replications since 2005, in the south and in the Cerrado of Minas Gerais, corresponding to municipalities of Lavras and Patrocinio, respectively (Table 1).

Table 1. Edaphoclimatic characteristics of each environment

\begin{tabular}{llllll}
\hline Enviroments & Altitude & Average Annual Temperature & Average Annual Rainfall & Latitude & Longitude \\
\hline Patrocínio & $966 \mathrm{~m}$ & $22^{\circ} \mathrm{C}$ & $1193 \mathrm{~mm}$ & $18^{\circ} 56^{\prime} 38^{\prime \prime} \mathrm{S}$ & $46^{\circ} 59^{\prime} 33^{\prime \prime} \mathrm{W}$ \\
Lavras & $950 \mathrm{~m}$ & $20.4^{\circ} \mathrm{C}$ & $1515 \mathrm{~mm}$ & $21^{\circ} 14^{\prime} 43^{\prime \prime} \mathrm{S}$ & $44^{\circ} 59^{\prime} 59^{\prime \prime} \mathrm{W}$ \\
\hline
\end{tabular}

For a better presentation of the discussion and results, the cultivars were coded as C1: Pau Brasil MG1; C2: Paraíso MGH419-1; C3: Sacramento; C4: Araponga MG1; C5: Oeiras MG6851; C6: Catigua MG1; C7: Catigua MG2; C8: Topázio MG1190, and C9: Bourbon Amarelo, and the environments were classified as A1: Patrocinio and A2: Lavras.

\subsection{Harvesting and Processing}

The coffee cherries were hand-picked and wet processed, yielding peeled cherry coffee (CD). The drying was held immediately following the peeling process in which 8 liters of peeled cherry coffee, from each plot, were arranged uniformly in $1 \mathrm{~m}^{2}$ sieves with screened bottoms on paved yard. The samples were turned 20 times per day until the beans reach an average of $11 \%$ water content (wb). After the drying process the samples were processed and the intrinsic and extrinsic defects removed, minimizing any interference that is not inherent in the genetic material or the cultivation environment.

\subsection{Roasting and Sensory Analysis}

The roasting and sensory analysis were performed on flat beans retained in sieve 16 and above, based on the protocols described by the Specialty Coffee Association of America (SCAA). The temperature $\left(160-200{ }^{\circ} \mathrm{C}\right)$ and time of roasting were monitored with thermometers and chronometers in the time range of 8 to $12 \mathrm{~min}$. For sensory analysis, a panel of three trained judges evaluated ten sensorial attributes (fragrance/aroma, consistency, absence of defects, sweetness, flavor, acidity, body, balance, finish, and overall impression), which were recorded on a scale of 0 to 10 points, according to the SCAA (Lingle, 2011). The final sensory score was generated from the sum of the evaluated attributes and specialty coffees are considered those scoring 80 or more points. The descriptions of the sensory characteristics of each sample and analyzed by the judges in accordance with the SCAA protocols were also recorded, allowing a better characterization of cultivars.

\subsection{Fatty Acids Profile}

The fatty acids were extracted from the samples according to Folch, Lees, and Stanley (1957). The analysis were performed in a gas chromatograh, model CG-17A, flame detector (FID) from Shimadzu. For the record and analysis of the chromatograms, the device is attached to a microcomputer, using the software GC Solution. The compounds were separated and identified in a capillary column Carbowax $(30 \mathrm{~m} \times 0.25 \mathrm{~mm})$. To the 
chromatografic separation, $1 \mu \mathrm{L}$ of sample was injected. Nitrogen was used as carrier gas at a linear velocity of $37.8 \mathrm{~cm} / \mathrm{s}$ and a split ratio of 1:5. The initial temperature of the column was of $200{ }^{\circ} \mathrm{C}$ (held for 2 minutes), increasing in $4{ }^{\circ} \mathrm{C}$ per minute until reaches $240{ }^{\circ} \mathrm{C}$ summing up 20 minutes of analysis. The flow of the gas drag in the column was of $1.0 \mathrm{~mL} / \mathrm{minute}$. The identification of the compounds was done through the time of retention from the related pattern.

\subsection{Statistical Analysis}

The results of the sensory attributes, final scores, content of fatty acids were subjected to analysis of variance (ANOVA) and, on detecting significant differences in the F test, the Scott-Knott test was used at 5\% significance. The data were also subjected to multivariate analysis to better understand the effect of the variables. Principal component analysis (PCA) was used to evaluate sample trends, starting from the interaction between cultivars and environments, resulting in the grouping of scores according to the sensory attributes and chemical composition. For this analysis, we used the statistical software R (R Development Core Team, 2015).

\section{Results and Discussion}

The relative (\%) of fatty acids, the sensorial attributes scores, the final score for each cultivar in the two studied environments, are presented in the Table 2.

Through the gas chromatography was possible to identify seven fatty acids in the raw grains of Arabica coffee. Being five of them fully studied in past studies with coffee, they are: palmitic acid, palmitoleic acid, stearic acid, oleic acid, linoleic acid, linolenic acid (D’Amélio et al., 2013; Bertrand et al., 2008; Jham et al., 2008; Joët et al., 2010; Martín et al., 2001; Vilarreal et al., 2009; Wagemaker et al., 2011). The presence of a fatty acid less common in coffee grains, the gamma linolenic acid, was also verified. 
Table 2. Scores of sensorial attributes and average values of fatty acids from different cultivars of Coffea arabica beans and its interactions with two environments: mean and significance probability $(F)$ determined by variance analysis (ANOVA) of two environments and nine cultivars with three replicates*

\begin{tabular}{|c|c|c|c|c|c|c|c|c|c|c|c|c|}
\hline Cult./envi.** & Frag. & Flav. & Acid. & Body & Final & C16:0 & C16:1 & C18:0 & C18:1 & $\mathrm{C} 18: 2 \omega-6$ & $\mathrm{C} 18: 3 \omega-6$ & $\mathrm{C} 18: 3 \omega-3$ \\
\hline $\mathrm{C} 1$ & 7.83 & $7.96 \mathrm{~b}$ & $7.58 \mathrm{~b}$ & 7.96 & $83.63 b$ & $27.01 \mathrm{~b}$ & $0.93 a$ & 6.04 & 9.44 & $41.44 \mathrm{~b}$ & $1.54 \mathrm{a}$ & $1.52 \mathrm{~b}$ \\
\hline $\mathrm{C} 2$ & 7.75 & $8.04 \mathrm{~b}$ & $7.58 \mathrm{~b}$ & 7.96 & $83.67 b$ & $30.53 \mathrm{a}$ & $0.74 \mathrm{a}$ & 5.88 & 8.77 & $40.70 \mathrm{~b}$ & $1.46 \mathrm{a}$ & $1.65 \mathrm{a}$ \\
\hline $\mathrm{C} 3$ & 7.58 & $7.96 \mathrm{~b}$ & $7.33 b$ & 7.96 & $82.58 \mathrm{~b}$ & $24.70 \mathrm{~b}$ & $0.47 \mathrm{~b}$ & 5.74 & 9.39 & $44.21 \mathrm{a}$ & $1.66 \mathrm{a}$ & $2.13 \mathrm{a}$ \\
\hline $\mathrm{C} 4$ & 8.17 & $8.42 \mathrm{a}$ & $7.92 \mathrm{a}$ & 8.04 & $85.46 \mathrm{a}$ & $28.36 \mathrm{a}$ & $0.00 \mathrm{c}$ & 5.43 & 9.15 & $43.65 \mathrm{a}$ & $1.04 \mathrm{~b}$ & $0.00 \mathrm{c}$ \\
\hline $\mathrm{C} 5$ & 7.83 & $8.00 \mathrm{~b}$ & $7.67 \mathrm{~b}$ & 7.96 & $83.33 b$ & $26.22 b$ & $0.89 \mathrm{a}$ & 6.74 & 8.84 & $42.65 \mathrm{a}$ & $1.45 \mathrm{a}$ & $1.90 \mathrm{a}$ \\
\hline C6 & 8.00 & $8.00 \mathrm{~b}$ & $7.63 b$ & 8.00 & $83.33 b$ & $27.50 \mathrm{~b}$ & $0.51 \mathrm{~b}$ & 6.39 & 8.93 & $43.27 \mathrm{a}$ & $1.53 \mathrm{a}$ & $0.89 \mathrm{~b}$ \\
\hline $\mathrm{C} 7$ & 8.08 & $8.33 \mathrm{a}$ & $7.86 \mathrm{a}$ & 8.17 & $85.71 \mathrm{a}$ & $29.74 a$ & $0.55 \mathrm{~b}$ & 6.66 & 10.03 & $39.10 \mathrm{~b}$ & $1.29 \mathrm{a}$ & $1.66 \mathrm{a}$ \\
\hline $\mathrm{C} 8$ & 7.75 & $7.83 \mathrm{~b}$ & $7.54 \mathrm{~b}$ & 7.92 & $82.58 \mathrm{~b}$ & $25.10 \mathrm{~b}$ & $0.23 \mathrm{c}$ & 5.39 & 10.04 & $43.28 \mathrm{a}$ & $0.63 b$ & $0.72 b$ \\
\hline C9 & 7.50 & $7.67 \mathrm{~b}$ & $7.38 \mathrm{~b}$ & 7.83 & $81.83 \mathrm{~b}$ & $24.06 \mathrm{~b}$ & $0.00 \mathrm{c}$ & 5.85 & 9.57 & $44.28 \mathrm{a}$ & $0.62 b$ & $0.86 \mathrm{~b}$ \\
\hline$F$ & 0.24 & 0.04 & 0.01 & 0.47 & 0.03 & 0.00 & 0.00 & 0.28 & 0.36 & 0.02 & 0.02 & 0.00 \\
\hline A1 & 7.80 & 8.01 & 7.56 & 7.94 & 83.43 & $25.79 \mathrm{~b}$ & $0.34 \mathrm{~b}$ & 6.23 & 9.21 & $43.85 \mathrm{a}$ & 1.24 & $0.95 \mathrm{~b}$ \\
\hline $\mathrm{A} 2$ & 7.87 & 8.04 & 7.67 & 8.02 & 83.94 & $28.26 \mathrm{a}$ & $0.62 \mathrm{a}$ & 5.79 & 9.49 & $41.17 \mathrm{~b}$ & 1.25 & $1.57 \mathrm{a}$ \\
\hline$F$ & 0.56 & 0.81 & 0.18 & 0.20 & 0.38 & 0.01 & 0.01 & 0.16 & 0.41 & 0.00 & 0.95 & 0.00 \\
\hline $\mathrm{A} 1 \mathrm{C} 1$ & 7.67 & 7.92 & 7.42 & 7.92 & 83.00 & $25.74 \mathrm{a}$ & $0.93 \mathrm{a}$ & 6.93 & 9.78 & $40.75 b$ & $1.56 \mathrm{~b}$ & $1.53 \mathrm{a}$ \\
\hline $\mathrm{A} 1 \mathrm{C} 2$ & 8.00 & 8.08 & 7.67 & 7.92 & 84.58 & $30.21 \mathrm{a}$ & $0.75 \mathrm{a}$ & 6.02 & 8.03 & $39.56 b$ & $1.36 \mathrm{c}$ & $1.73 \mathrm{a}$ \\
\hline A1C3 & 7.50 & 7.92 & 7.33 & 7.92 & 82.17 & $25.94 \mathrm{a}$ & $0.00 \mathrm{~b}$ & 5.74 & 9.35 & $46.50 \mathrm{a}$ & $1.33 \mathrm{c}$ & $2.14 \mathrm{a}$ \\
\hline $\mathrm{A} 1 \mathrm{C} 4$ & 8.00 & 8.50 & 7.92 & 7.92 & 85.08 & $28.10 \mathrm{a}$ & $0.00 \mathrm{~b}$ & 5.03 & 8.18 & $44.25 \mathrm{a}$ & $2.08 \mathrm{a}$ & $0.00 \mathrm{~b}$ \\
\hline A1C5 & 7.67 & 8.00 & 7.33 & 7.92 & 82.67 & $28.14 \mathrm{a}$ & $0.65 \mathrm{a}$ & 6.66 & 9.01 & $43.43 \mathrm{a}$ & $1.65 \mathrm{~b}$ & $1.61 \mathrm{a}$ \\
\hline A1C6 & 8.00 & 8.00 & 7.50 & 8.00 & 83.50 & $23.16 \mathrm{~b}$ & $0.73 \mathrm{a}$ & 7.10 & 9.51 & $46.05 \mathrm{a}$ & $1.58 \mathrm{~b}$ & $0.00 \mathrm{~b}$ \\
\hline $\mathrm{A} 1 \mathrm{C} 7$ & 8.00 & 8.00 & 7.75 & 8.00 & 84.50 & $28.19 \mathrm{a}$ & $0.00 \mathrm{~b}$ & 7.40 & 10.21 & $40.93 b$ & $1.61 \mathrm{~b}$ & $1.51 \mathrm{a}$ \\
\hline $\mathrm{A} 1 \mathrm{C} 8$ & 7.67 & 7.67 & 7.58 & 7.83 & 82.17 & $21.43 b$ & $0.00 \mathrm{~b}$ & 5.37 & 8.59 & $47.74 \mathrm{a}$ & $0.00 \mathrm{~d}$ & $0.00 \mathrm{~b}$ \\
\hline A1C9 & 7.67 & 8.00 & 7.50 & 8.00 & 83.17 & $21.19 \mathrm{~b}$ & $0.00 \mathrm{~b}$ & 5.84 & 10.23 & $45.42 \mathrm{a}$ & $0.00 \mathrm{~d}$ & $0.00 \mathrm{~b}$ \\
\hline$F$ & 0.93 & 0.60 & 0.35 & 0.89 & 0.80 & 0.01 & 0.00 & 0.46 & 0.14 & 0.00 & 0.00 & 0.00 \\
\hline $\mathrm{A} 2 \mathrm{C} 1$ & 8.00 & $8.00 \mathrm{~b}$ & $7.75 \mathrm{a}$ & 8.00 & $84.25 \mathrm{a}$ & $28.27 \mathrm{~b}$ & $0.93 \mathrm{a}$ & $5.15 \mathrm{~b}$ & $9.10 \mathrm{c}$ & 42.13 & $1.51 \mathrm{a}$ & $1.51 \mathrm{a}$ \\
\hline $\mathrm{A} 2 \mathrm{C} 2$ & 7.50 & $8.00 \mathrm{~b}$ & $7.50 \mathrm{~b}$ & 8.00 & $83.00 \mathrm{~b}$ & $30.86 a$ & $0.74 \mathrm{a}$ & $5.75 \mathrm{~b}$ & $9.52 b$ & 41.85 & $1.57 \mathrm{a}$ & $1.57 \mathrm{a}$ \\
\hline $\mathrm{A} 2 \mathrm{C} 3$ & 7.67 & $8.00 \mathrm{~b}$ & $7.33 b$ & 8.00 & $82.75 b$ & $23.46 \mathrm{~d}$ & $0.94 \mathrm{a}$ & $5.74 \mathrm{~b}$ & $9.43 b$ & 41.92 & $1.9 \mathrm{a}$ & $2.13 \mathrm{a}$ \\
\hline $\mathrm{A} 2 \mathrm{C} 4$ & 8.33 & $8.33 b$ & 7.92a & 8.17 & $85.83 \mathrm{a}$ & $28.62 b$ & $0.00 \mathrm{c}$ & $5.82 \mathrm{~b}$ & $10.12 b$ & 43.06 & $0.00 \mathrm{~b}$ & $0.00 \mathrm{~b}$ \\
\hline A2C 5 & 8.00 & $8.00 \mathrm{~b}$ & $8.00 \mathrm{a}$ & 8.00 & $85.00 \mathrm{a}$ & $24.29 \mathrm{~d}$ & $1.13 \mathrm{a}$ & $6.82 \mathrm{a}$ & $8.67 \mathrm{c}$ & 41.87 & $1.25 \mathrm{a}$ & $2.19 \mathrm{a}$ \\
\hline A2C6 & 8.00 & $8.00 \mathrm{~b}$ & $7.75 \mathrm{a}$ & 8.00 & $84.17 \mathrm{a}$ & $31.83 \mathrm{a}$ & $0.29 b$ & $5.69 \mathrm{~b}$ & $8.36 \mathrm{c}$ & 40.49 & $1.49 \mathrm{a}$ & $1.79 \mathrm{a}$ \\
\hline $\mathrm{A} 2 \mathrm{C} 7$ & 8.17 & $8.67 \mathrm{a}$ & $8.00 \mathrm{a}$ & 8.33 & $86.92 \mathrm{a}$ & $31.29 \mathrm{a}$ & $1.09 \mathrm{a}$ & $5.92 b$ & $9.85 b$ & 37.26 & $0.97 \mathrm{a}$ & $1.80 \mathrm{a}$ \\
\hline $\mathrm{A} 2 \mathrm{C} 8$ & 7.83 & $8.00 \mathrm{~b}$ & $7.50 \mathrm{~b}$ & 8.00 & $83.00 \mathrm{~b}$ & $28.77 \mathrm{~b}$ & $0.46 b$ & $5.41 \mathrm{~b}$ & $11.49 \mathrm{a}$ & 38.83 & $1.26 \mathrm{a}$ & $1.44 \mathrm{a}$ \\
\hline $\mathrm{A} 2 \mathrm{C} 9$ & 7.83 & $7.33 \mathrm{c}$ & $7.25 b$ & 7.67 & $80.50 \mathrm{c}$ & $26.94 \mathrm{c}$ & $0.00 \mathrm{c}$ & $5.86 \mathrm{~b}$ & $8.90 \mathrm{c}$ & 43.15 & $1.23 \mathrm{a}$ & $1.72 \mathrm{a}$ \\
\hline$F$ & 0.06 & 0.01 & 0.00 & 0.37 & 0.00 & 0.00 & 0.00 & 0.04 & 0.00 & 0.15 & 0.00 & 0.00 \\
\hline
\end{tabular}

Note. ${ }^{*}$ Averages followed by the same letter do not differentiate among each other by the Scott-Knot test, to the $5 \%$ significance level.

** Cult./Envi. $=$ Cultivars/Environments. Frag. $=$ Fragrance, Flav. $=$ Flavor, Acid. $=$ Acidity, Final $=$ Final Score. $\mathrm{C} 16: 0=$ palmitic acid, $\mathrm{C} 16: 1=$ palmitoleic acid, $\mathrm{C} 18: 0=$ stearic acid, $\mathrm{C} 18: 1=$ oleic, $\mathrm{C} 18: 2 \omega-6=$ linoleic, $\mathrm{C} 18: 3$ $\omega-6(G L A)=$ gamma-linolenic, C18:3 $\omega-3=$ linolenic. $\mathrm{C} 1=$ Pau Brasil MG1, C2 = Paraíso MGH419-1, C3 = Sacramento MG1, C4 = Araponga MG1, C5 = Oeiras MG6851, C6 = Catiguá MG1, C7 = Catiguá MG2, C8 = Topázio MG1190, C9 = Bourbon Amarelo, A1 = Patrocínio, A2 = Lavras.

According to the results shown on Table 2, can be seen that among the fatty acid found on raw grains of the studied cultivars, the linoleic acids (C18:2) and palmitic (C16:0) were prevalent. The fatty stearic acid (C18:0), oleic (C18:1), gamma linoleic (C18:3 $\omega-6)$ and linolenic (C18:3 $\omega-3)$ show intermediate concentration, while the palmitoleic acid shows lower values than $1 \%$.

There was a significant difference between the evaluated cultivar for most of the fatty acids, except to the stearic and oleic acids. This fact was not observed by Figueiredo et al. (2015) and Jham et al. (Jham et al., 2008) in studies with C. arabica cultivars. However, Martín et al. (2001) could distinguish genotypes of C. arabica and C. canephora through the content of the fatty acids. This variability found on this present work of the evaluated cultivar as, which are arising from the crossbreeding of Coffea arabica with Coffea canephora, could be elucidated 
by the difference in the content of lipids among these two species. The arabica species shows values around $15 \%$ and the robusta species $10 \%$ of lipids. The content of lipids to the Coffea genre is highly variable, beyond the variation between the arabica and canephora. Wagemaker et al. (2011) report that the species, Coffea heterocalyx and Coffea salvatrix, can hold from 20 to $30 \%$ of lipids.

The content of palmitic, palmitoleic, linoleic and linolenic acids allowed the distinction of the studied environments through $\mathrm{F}$ test under $\mathrm{p}<0.05$. The influence of the weather conditions shown in the environments about the composition of fatty acids in coffee seeds is still not much studied (Joët et al., 2010). However, the studies of Bertrand et al. (2008) with Caturra and the hybrid genotypes, in the environments Naranjal, Paraguaicito and Rosario in Colombia show that the content of the fatty acids in raw coffee grains is able to distinguish environments in an efficient way.

Also is noticed that the interactions between the two environments and the studied cultivars varied significantly (Table 2). In the environment A1 (Patrocinio), only the stearic and the oleic acids did not show difference among the cultivars. In the environment A2 (Lavras) only the linoleic acid did not show significant difference. It also noted that inside the interaction with the environment A2, the palmitic acid showed a greater difference among the studied cultivars. Villarreal et al. (2009), studying the genotypes effects and environments in the fatty acids profile, showed that the palmitic acid explained a significant total variance percentage to genotypes and environments, but when there is the interaction between them, this acid is quite helpless explaining the total variance percentage.

The gas capillary chromatography allowed quantify beyond the fatty acids commonly found in coffee grains, the fatty acid gamma linolenic (C18:3 $\omega-6$, GLA). The gamma linolenic fatty acid (GLA) is a metabolite from the linoleic fatty acid and the first intermediate in the conversion of linoleic acid into arachidonic acid (Gustone, 1992) It is widely found in plants (Guil-Guerreiro, 2000; Knothe, 2013; Tso et al., 2013; Rojo et al., 2010). Some researchers have shown through the microbiologic analysis, that the gamma linolenic acid beyond its healing and nutritional characteristics, this fatty acid also shows antimicrobial characteristic (Desbois \& Lawlor, 2013; Clement et al., 2008; Giamarellos-Bourboulis et al., 2004; Ramadan et al., 2008).

\subsection{Principal Component Analysis}

For the better understanding of the cultivar effect as well as the interaction between the two factors in the fatty acid profile, the Figure 1 shows the biplot of the multivariate analysis of the data, made through the principal component analysis (PCA). According to Figure 1, the principal two first components explained $76.85 \%$ of the variability between the studied cultivars. The interaction between the cultivars and environments $\left(A_{x} C_{y}\right)$ are represented by the points and the vectors by the studied variables (sensorial attributes and fatty acids). 


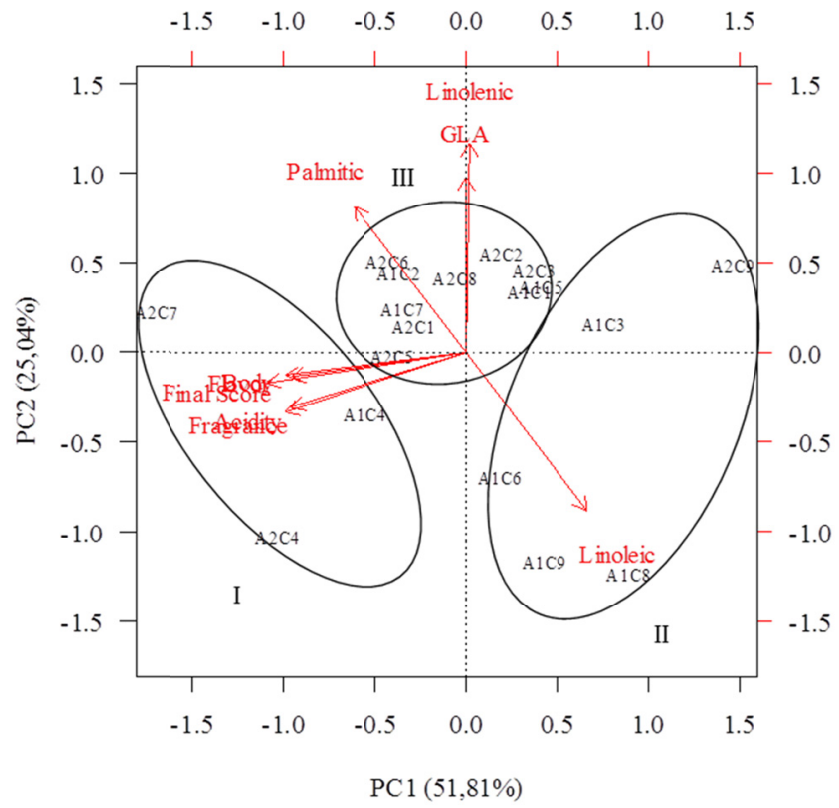

Figure 1. Biplot of the two first axes of the principal components analysis for data of nine cultivars (C) and two environments (A), according to the attributes and the final score and the palmitic, linoleic, linolenic and gamma

linolenic fatty acids (GLA). C1 = Pau Brasil MG1, C2 = Paraíso MGH419-1, C3 = Sacramento MG1, C4 =

Araponga MG1, C5 = Oeiras MG6851, C6= Catiguá MG1, C7 = Catiguá MG2, C8 = Topázio MG1190, C9 =

Bourbon Amarelo, A1 = Patrocínio, A2 = Lavras

The sensorial attributes fragrance, flavor, acidity, body and final score determine the development of the first principal component (PC1). The second component (PC2) was determined by the palmitic, linoleic, linolenic and gamma linolenic fatty acids (Table 3). The other fatty acids found in the cultivars (oleic, palmitoleic and stearic) show almost null contribution for the total variation, not being, therefore crucial for the final result of this analysis.

Table 3. Descriptive statistics and correlations between the parameters assessed (final score, sensory attributes and fatty acid) with the first two principal components and the respective coefficients each parameter with the principal component

\begin{tabular}{llllllll}
\hline \multirow{2}{*}{ Parameters } & \multirow{2}{*}{ Mean } & \multirow{2}{*}{ Standard Deviation } & \multicolumn{2}{c}{ PC1 } & & \multicolumn{2}{c}{ PC2 } \\
\cline { 5 - 7 } \cline { 6 - 7 } & & & Coeficients & Correlations* & & Coeficients & Correlations* \\
\hline Fragrance & 7.83 & 0.26 & -0.412 & $\mathbf{- 0 . 8 9 0 6}$ & & -0.165 & -0.2474 \\
Flavor & 8.02 & 0.28 & -0.411 & $\mathbf{- 0 . 8 8 7 6}$ & & 0.000 & -0.0948 \\
Acidity & 7.61 & 0.24 & -0.399 & $\mathbf{- 0 . 8 6 1 7}$ & & -0.152 & -0.2278 \\
Body & 7.98 & 0.13 & -0.397 & $\mathbf{- 0 . 8 5 6 7}$ & & 0.000 & -0.0992 \\
Final Score & 83.68 & 1.52 & -0.452 & $\mathbf{- 0 . 9 7 6 6}$ & & 0.000 & -0.1258 \\
Palmitic & 27.02 & 3.26 & -0.253 & -0.5474 & & 0.407 & 0.6107 \\
Linoleic & 42.51 & 2.76 & 0.275 & 0.5932 & & -0.439 & $\mathbf{- 0 . 6 5 9 5}$ \\
GLA & 1.25 & 0.63 & 0.000 & 0.0008 & & 0.487 & 0.7305 \\
Linolenic & 1.26 & 0.83 & 0.000 & 0.0185 & & 0.582 & 0.8744 \\
\hline
\end{tabular}

Note. * Variables in bold and italic indicate groups of variables to be formed, characterized by variables whose correlation with principal component are high and with same signal.

It is noticed that the development of three different groups of cultivars $\times$ environments. In the right side of the biplot are assigned the matters of the second (II) group (A1C3, A1C8, A1C9, A1C6 and A2C9). The matters assigned on the left side of the biplot form the first (I) group (A1C4, A2C4 and $\mathrm{A} 2 \mathrm{C} 7$ ), and the matters assigned on the central part of the biplot form the third (III) group of environments and cultivars (A1C1, A2C1, A1C2, $\mathrm{A} 2 \mathrm{C} 2$, $\mathrm{A} 2 \mathrm{C} 3, \mathrm{~A} 1 \mathrm{C} 5, \mathrm{~A} 2 \mathrm{C} 5, \mathrm{~A} 2 \mathrm{C} 6, \mathrm{~A} 1 \mathrm{C} 7$ and $\mathrm{A} 2 \mathrm{C} 8$ ). 
The belonging coffee of the first group and to the second group are the coffee that show higher and lower sensorial score, respectively. In addition, to the coffee of the group III, intermediate sensorial score (Table 2).

In same way that has been seen in sensory analysis, the final score presented highest standard deviation and high correlation between another sensory attributes. However, the sensory attributes presented poor correlation with fatty acid (Table 3) and high correlation with second principal component (Table 3). As in the first case, the first component is viewed as a quality coffee indicator according its sensorial attributes and the second component is viewed as a fatty acid coffee indicator.

On Figure 2 is the chart of scores of $\mathrm{PC} 1$ to each cultivar and environment in which is noticed the coffee that are in the rod of negative direction of the graphic are the coffee with higher sensorial attributes, and the coffee with rods in the positive direction of the graphic are the coffee with lower sensorial attributes. The Catigua MG2 and Araponga MG1 cultivars are the resistant cultivars to leaf rust with higher potential to the production of specialty coffee.

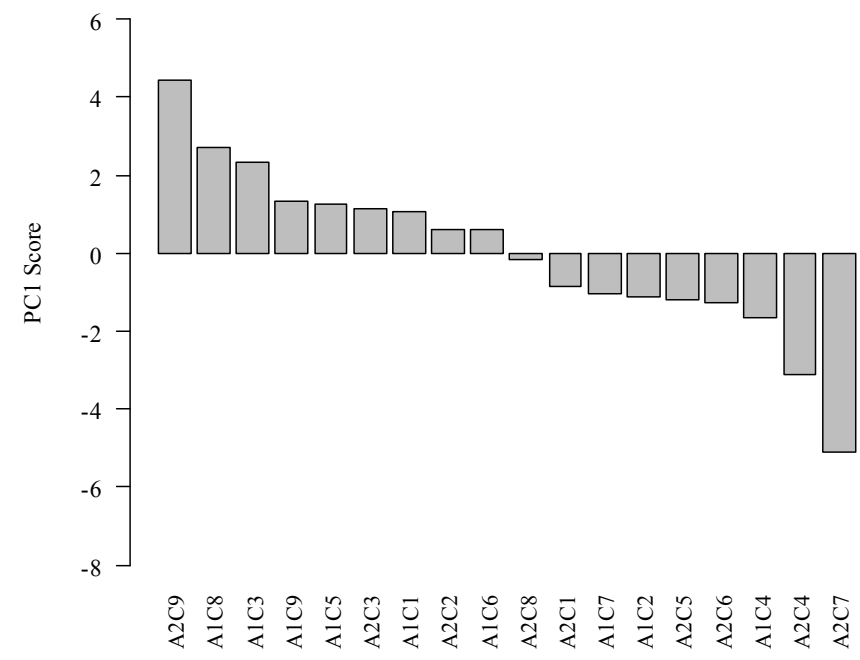

Figure 2. Scores from PC1 for data of nine cultivars (C) and two environments (A), in relation to the sensorial attributes and to the final score and to the fatty acids. C1 = Pau Brasil MG1, C2 = Paraíso MGH419-1, C3 = Sacramento MG1, C4 = Araponga MG1, C5 = Oeiras MG6851, C6 = Catiguá MG1, C7 = Catiguá MG2, C8 = Topázio MG1190, C9 = Bourbon Amarelo, A1 = Patrocínio, A2 = Lavras

The sensorial attributes fragrance, flavor, acidity, body and final score show negative scores (Table3) so, between the fatty acids that had good explanation with the PC1, moreover, with the quality of the coffee (palmitic and linoleic acids), only the palmitic fatty acids had moderate correlation of same direction with the sensorial attributes, once that also showed negative correlation. The linoleic acid also had moderate correlation with the sensorial attributes, however in opposite direction (Table 4), being decisive to gather the coffee with lower sensorial score. (Figure 1, Table 2).

Figueiredo et al. (2015) report in their studies that the palmitic, stearic, arachidic and elaidic fatty acids show correlation with the sensorial attributes of the Bourbon coffee, as being that the first pair correlated better with coffee with higher sensorial grades and the second pair with the coffee with lower grades. The authors suggest that such fatty acids can be possible distinguishers of the coffee quality.

For the evaluated cultivars in this present study, the palmitic and linoleic acids are the possible distinguishers of quality, because show correlation with the sensorial attributes.

The profile of fatty acids can be used as tracer of a cultivar and can inform about the main qualities of the coffee (Alves et al., 2003). The fatty acids play a role in a series of catabolic reactions that lead to the production of compounds of flavor and aroma typical in food (Collins et al., 2003), and have capacity to cover the tongue during the digestion, providing an fatty and creamy buccal sensation, typical of the body of the drink. However, the unsaturated fatty acids, as linoleic, linolenic, and oleic due to the facility to suffer oxidation, in many cases are related with the development of unwanted flavors in vegetal oils (Illy \& Viani, 2005; Jham et al., 2008). 
Using the correlation matrix in Table 4, it has had that the null hypothesis that the correlation matrix is an identity was rejected $(p<0.05)$.

Table 4. Correlations between each parameter assessed (final score, sensory attributes and fatty acid) and results of the $t$-Student test that population correlation is different from zero

\begin{tabular}{llllllllll}
\hline Parameters & Fragrance & Flavor & Acidity & Body & Final Score & Palmitic & Linoleic & GLA & Linolenic \\
\hline Fragrance & 1.00 & $0.72^{*}$ & $0.85^{*}$ & $0.70^{*}$ & $0.91^{*}$ & 0.32 & -0.36 & -0.11 & -0.25 \\
Flavor & $0.75^{*}$ & 1.00 & $0.69^{*}$ & $0.82^{*}$ & $0.88^{*}$ & 0.40 & -0.38 & 0.07 & -0.16 \\
Acidity & $0.85^{*}$ & $0.69^{*}$ & 1.00 & $0.61^{*}$ & $0.90^{*}$ & 0.33 & -0.33 & -0.15 & -0.17 \\
Body & $0.70^{*}$ & $0.82^{*}$ & $0.61^{*}$ & 1.00 & $0.82^{*}$ & 0.32 & -0.46 & -0.16 & -0.02 \\
Final Score & $0.91^{*}$ & $0.88^{*}$ & $0.90^{*}$ & $0.82^{*}$ & 1.00 & 0.40 & $-0.47^{*}$ & -0.05 & -0.09 \\
Palmitic & 0.32 & 0.40 & 0.33 & 0.32 & 0.40 & 1.00 & $-0.70^{*}$ & 0.33 & 0.39 \\
Linoleic & -0.36 & -0.38 & -0.33 & -0.46 & $-0.47^{*}$ & $-0.70^{*}$ & 1.00 & -0.30 & $-0.56^{*}$ \\
GLA & -0.11 & 0.07 & -0.15 & -0.16 & -0.05 & 0.33 & -0.30 & 1.00 & $0.50^{*}$ \\
Linolenic & -0.25 & -0.16 & -0.17 & -0.02 & -0.09 & 0.39 & $-0.56^{*}$ & $0.50^{*}$ & 1.00 \\
\hline
\end{tabular}

Note. $*$ if $p<0.05$, it rejects null hypothesis that populational correlation is equal to zero.

The Figure 3 represents the scores from the interactions cultivars $x$ environments to the second principal component (PC2). Once that the PC2 was determined by the content of fatty acids from the coffee evaluated, and that the linoleic fatty acid presented negative scores, and the palmitic, linolenic and gamma linolenic fatty acids show higher and were more representative on this component and also positive (Table 3 ). Is seen that the cultivars that are on the negative bar of the chart are the ones with higher amounts of linoleic acids, so, A1C8 and A1C9 (Topazio and Bourbon Amarelo, respectively, grown in Patrocinio). The cultivar A2C2 Paraíso/Lavras (on the positive side of the chart) is which present higher values of palmitic, linolenic and gamma linolenic acids. The cultivar that is between these two characteristics (A2C5-Oeiras MG6851/Lavras) shows intermediate values for all the fatty acids.

Considering that, is possible to point out that the majority of the cultivars that interact with the environment (Patrocinio) show higher values of linoleic fatty acids and the one that interact with the A2 environment (Lavras), show higher values of palmitic, linolenic and gamma linolenic fatty acids. Moreover, these fatty acids are possible environment differentiators. Corroborating with the seen result, Bertrand et al (2008) in studies about the profile of fatty acids in different environments and genotypes, show that the majority of the fatty acids present in the different coffee grains are capable to differentiate environments, considering that some acids show higher potential for this differentiation. 


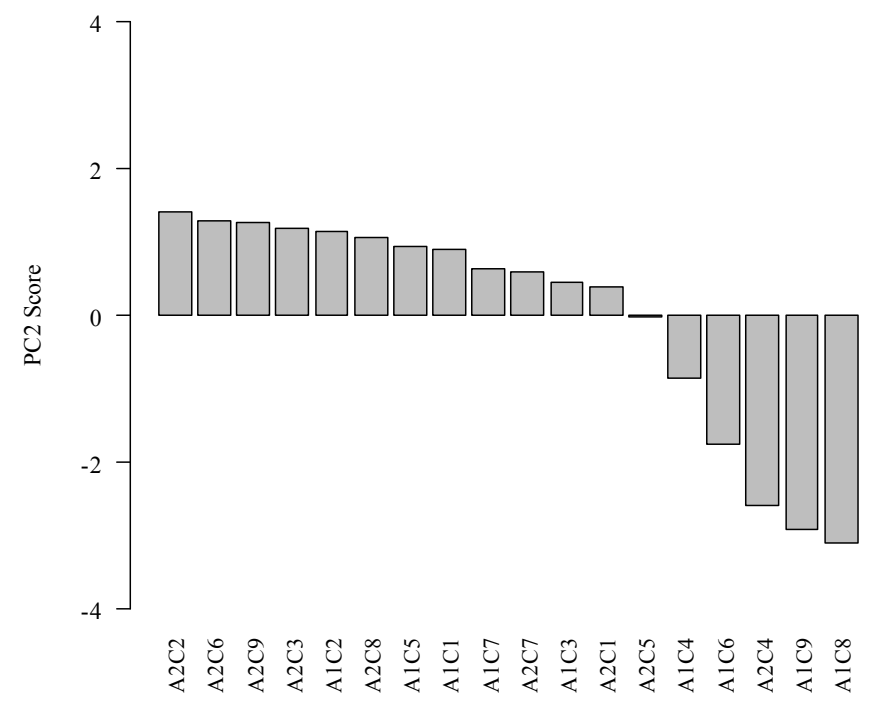

Figure 3. Scores from PC2 for data of nine cultivars (C) and two environments (A), in relation to the sensorial attributes and to the final score and to the fatty acids. C1 = Pau Brasil MG1, C2 = Paraíso MGH419-1, C3 = Sacramento MG1, C4 = Araponga MG1, C5 = Oeiras MG6851, C6 = Catiguá MG1, C7 = Catiguá MG2, C8= Topázio MG1190, C9 = Bourbon Amarelo, A1 = Patrocínio, A2 = Lavras

The coffee are defined as intermediaries in the present study, performed in higher number (coffee allocated in group III), and with greater proximity between the points for the chemical compounds studied. This fact demonstrates the possibility of cultivars arising from crosses show to have more variability in chemistry, a fact also observed by Fassio et al. (2016) when evaluating the caffeine, 5-AQC and trigonelline compounds in cultivars resistant to rust.

\section{Conclusion}

The profile of the fatty acids permitted differentiate the leaf rust resistant cultivars, the environments as also the interaction between these two matters related to the sensorial quality.

The palmitic, linoleic fatty acids were crucial to differentiate the quality of leaf rust resistant cultivars.

The analysis of principal components showed to be efficient to differentiate the Patrocinio environment, considering the composition of the linoleic fatty acid and the Lavras environment considering the composition of the linolenic, gamma linolenic and palmitic fatty acids.

\section{Acknowledgements}

The authors thank the Consórcio Pesquisa Café, the FAPEMIG, the CNPq, the CAPES by financed this work, and the Empresa de Pesquisa Agropecuária de Minas Gerais and the Universidade Federal de Lavras for the support.

\section{References}

Alves, M. R., Casal, S., Oliveira, M. B. P. P., \& Ferreira, M. A. (2003). Contribution of FA profile obtained by high-resolution $\mathrm{GC} / \mathrm{chemometric}$ techniques to the authenticity of green and roasted coffee varieties. $J$ of the America Oil Chem Soc, 80, 511-517. https://doi.org/10.1007/s11746-003-0730-0

Bertrand, B., Villarreal, D., Laffargue, A., Posada, H., Lashermes, P., \& Dussert, S. (2008). Comparison of the effectiveness os fatty acids, chlorogenic acids, and elements for the chemometric discrimation of coffee (Coffea Arabica L.) varieties and growing origins. J of Agric and Food Chem, 56, 2273-2280. https://doi.org/10.1021/jf073314f

Borém, F. M., Ribeiro, F. C., Figueiredo, L. P., Giomo, G. S., Fortunato, V. A., \& Isquierdo, E. P. (2013). Evaluation of the sensory and color quality of coffee beans stored in hermetic packaging. J of Stored Prod Res, 52, 1-6. https://doi.org/10.1016/j.jspr.2012.08.004

Clement, M., Tremblay, J., Lange, M., Thibodeau, J., \& Belhumeur, P. (2008). Purification and identification of bovine cheese whey fatty acid exhibiting in vitro antifungal activity. $J$ of Dairy Sci, 91, 2535-2544. https://doi.org/10.3168/jds.2007-0806 
Clifford, M. N. (1985). Chemical and physical aspects of green coffee and coffee products. Coffee: Botany, biochemistry and production of beans and beverage (pp. 305-374). Croom Helm, New York. https://doi.org/10.1007/978-1-4615-6657-1_13

Collins, F. Y., McSweeneyb, P. L. H., \& Wilkinsonc, M. G. (2003). Lipolysis and free fatty acid catabolism in cheese: A review of current knowledge. Inter Dairy J, 13, 841-866. https://doi.org/10.1016/S0958-6946 (03)00109-2

D’Amelio, N., De Angelis, E., Navarini, L., Schievano, E., \& Mammi, S. (2013). Green coffee oil analysis by high-resolution nuclear magnetic resonance spectroscopy. Talanta, 110, 118-127. https://doi.org/10.1016/ j.talanta.2013.02.024

Desbois, A. P., \& Lawlor, K. C. (2013). Antimicrobial activity of long-chain polyunsaturated fatty acids against Propionibacterium acnes and Staphylococcus aureus. Marine Drugs, 11, 4544-4557. https://doi.org/10.3390/ md11114544

Fassio, L. O., Malta, M. R., Carvalho, G. R., Liska, G. R., Lima, P. M., \& Pimenta, C. J. (2016). Sensory description of cultivars (Coffea Arabica L.) resistant to rust and its correlation with caffeine, trigonelline, and chlorogenic acid compounds. Beverages, 2, 2-12. https://doi.org/10.3390/beverages2010001

Figueiredo, L. P., Borém, F. M., Ribeiro, F. C., Giomo, G. S., Taveira, J. H. S., \& Malta, M. R. (2015). Fatty acids profile and parameters of quality of specialty coffee produced in different Brazilian regions. African $J$ of Agric Res, 10, 3484-3493. https://doi.org/10.5897/AJAR2015.9697

Folch, J., Lees, M., \& Stanley, G. H. S. (1957). A simple method for the isolation and purification of total lipids from animal tissues. J of Bio Chem, 226, 497-509.

Franca, A. S., Mendonça, J. C. F., \& Oliveira, S. D. (2005). Composition of green and roasted coffees of different cup qualities. LWT-Food Sci and Tech, 38, 709-715. https://doi.org/10.1016/j.lwt.2004.08.014

Giamarellos-Bourboulis, E. J., Mouktaroudi, M., Adamis, T., Koussoulas, V., Baziaka, F., Perrea, D., ... Giamarellou, H. (2004). n-6 polyunsaturated fatty acids enhance the activities of ceftazidime and amikacin in experimental sepsis caused by multidrug-resistant Pseudomonas aeruginosa. Antimicro Agents and Chem, 48, 4713-4717. https://doi.org/10.1128/AAC.48.12.4713-4717.2004

Guil-Guerreiro, J. L. (2000). Occurrence and characterization of oils rich in g-linolenic acid: Part I, Echium seeds from Macaronesia. Phytochemistry, 53, 451-456. https://doi.org/10.1016/S0031-9422(99)00549-X

Gunstone, F. D. (1992). Gamma-linolenic acid: Occourrence and physical and chemical properties. Progress in Lip Res, 31, 145-161. https://doi.org/10.1016/0163-7827(92)90007-6

Gutkoski, L. C., \& El-Dash, A. A. (1999). Effect of extrusion process variables on physical and chemical properties of extruded oat products. Plant Foods for Hum Nut, 54, 315-325. https://doi.org/10.1023/ A:1008101209353

Illy, A., \& Viani, R. (2005). Espresso coffee: The science of quality (p. 398). Academic, London.

Jham, G. N., Berhow, M. A., Manthey, L. K., Palmquist, D. A., \& Vaughn, S. F. (2008). The use of fatty acid profile as potential makers for Brazilian coffee (Coffea Arabica L.) for corn adulteration. $J$ of the Brazilian Chem Soc, 19, 1462-1467. https://doi.org/10.1590/S0103-50532008000800004

Joët, T., Laffargue, A., Descroix, F., Doulbeau, S., Bertrand, B., Kochko, A., \& Dussert, S. (2010). Influence of environmental factors, wet processing and the interactions on the biochemical composition of green Arabica coffee beans. Food Chem., 118, 693-701. https://doi.org/10.1016/j.foodchem.2009.05.048

Knothe, G. (2013). Fuel properties of methyl esters of borage and black currant oils containing methyl $\gamma$-linolenate. European J of Lip Sci and Tech, 115, 901-908. https://doi.org/10.1002/ejlt.201300061

Lingle, T. R. (2011). The coffee cupper's handbook: Systematic guide to the sensory evaluation of coffee's flavor (p. 66). Specialty Coffee Association of America, Long Beach.

Martín, M. X., Pablos, F., González, A. G., Valdenebro, M. X., \& León-Camacho, M. (2001). Fatty acid profiles as discriminant parameters for coffee varieties differentiation. Talanta, 54, 291-297. https://doi.org/10.1016/ S0039-9140(00)00647-0

R Development Core Team. (2013). R: A language and environment for statistical computing. Foundation for Statistical Computing, Viena. Retrieved from http://www.R-project.org 
Ramadan, M. F., Asker, M. M. S., \& Ibrahim, Z. K. (2008). Functional bioactive compounds and biological activities of Spirulina platensis lipids. Czech J Food Sci, 26, 211-222.

Rojo, L. E., Villano, C. M., Joseph, G., Schmidt, B., Shulaev, V., Shuman, J. L., ... Raskin, I. (2010). Wound-healing properties of nut oil from Pouteria lucuma. $J$ of Cosmetic Derm, 9, 185-195. https://doi.org/10.1111/j.1473-2165.2010.00509.x

Speer, K., \& Kölling-Speer, I. (2006). The lipid fraction of the coffee bean. Brazilian J of Plant Physiology, 18, 201-216. https://doi.org/10.1590/S1677-04202006000100014

Tso, P., Caldwell, J., Lee, D., Boivin, G. P., \& DeMichele, S. J. (2012). Comparison of growth, serum biochemistries and $\mathrm{n} 6$ fatty acid metabolism in rats fed diets supplemented with high-gamma-linolenic acids a flower oil or borage oil for 90 days. Food and Chem Toxic, 50, 1911-1919. https://doi.org/10.1016/ j.fct.2012.01.001

Vilas Boas, B. M., Licciardi, R., Moraes, A. R., \& Carvalho, V. D. (2001). Seleção de extratores e tempo de extração para determinação de açúcares em café torrado. Ciência e Agrot, 25, 1169-1173.

Villarreal, D., Laffargue, A., Posada, H., Bertrand, B., Lashermes, P., \& Dussert, S. (2009). Genotypic and environmental effect on coffee (Coffea arabica L.) bean fatty acid profile: impact on variety and origin chemometric determination. $J$ of Agric and Food Chem, 57, 11321-11327. https://doi.org/10.1021/ jf902441n

Wagemaker, T. A. L., Carvalho, C. R. L., Maia, N. B., Baggio, S. R., \& Filho, O. G. (2011). Sun protection factor, content and composition of lipid fraction of green coffee beans. Ind Crops and Prod, 33, 469-473. https://doi.org/10.1016/j.indcrop.2010.10.026

\section{Copyrights}

Copyright for this article is retained by the author(s), with first publication rights granted to the journal.

This is an open-access article distributed under the terms and conditions of the Creative Commons Attribution license (http://creativecommons.org/licenses/by/4.0/). 